\title{
ALK-negative anaplastic large cell lymphoma
}

INSERM

\section{Source}

INSERM. (1999). Orphanet: an online rare disease and orphan drug data base. ALKnegative anaplastic large cell lymphoma. ORPHA:300903

ALK-negative anaplastic large cell lymphoma (ALK- ALCL) is a type of ALCL (see this term), a rare and aggressive peripheral T-cell non-Hodgkin lymphoma affecting lymph nodes and extranodal sites, which is characterized by the lack of expression of a protein called anaplastic lymphoma kinase (ALK). 